\title{
Non-Revenue Water Works in Jordan- Lessons Learnt and Suggested Strategy and Workplan
}

\author{
Mohanned S. Al-Sheriadeh ${ }^{1}$ and Lubna K Amayreh ${ }^{2}$ \\ ${ }^{1}$ Civil Engineering Department, College of Engineering/Jordan University of Science \& Technology, Jordan. \\ ${ }^{2}$ Civil Engineering Department, College of Engineering/ Applied Science Private University, Jordan. \\ ORCID: 0000-0002-4284-0126 (Mohanned S. Al-Sheriadeh)
}

\begin{abstract}
Non-revenue water is still high in Jordan, albeit all efforts spent since 2000. Previous pilot projects have highlighted the main causes as supply intermittency, meters' inaccuracies, high pressure, illegal uses, intermingled networks, finance and management. From lessons learnt from pilot projects we propose herein a new strategy and work plan. It relied on answering these four questions: How much water is being lost? Where is being lost from? How to improve performance? How to maintain the strategy? This strategy and work plan prioritize areas and actions on which non-revenue water must be estimated accurately. Once accomplished, it will move to the next priority areas based on financial and so forth constraints. The strategy will be sustainable by financial aid provided on good performance. The proposed strategy is simple and fits resources, not comprehensive and complicated as the one suggested nowadays in Jordan.
\end{abstract}

Keywords: Action plan, Jordan, Non-revenue water, Pilot projects, Strategy.

\section{INTRODUCTION}

Although Jordan is one of three most water poor countries in the world, it is still losing more than $50 \%$ of its water in the water networks in the form of non-revenue water (NRW). The quantity is still large, though considerable resources have been allocated since 2000. Several factors contributed to this dilemma, such as the supply intermittency, the way the networks are intermingled together, high-pressure in some areas, the way water utilities are managed, layout and maintenance practices, existing policies and strategies, and the lack of a strong institutional resolve, etc.

Many countries like Jordan suffer from the same problem, which urged the International Water Association (IWA) in the past few decades to form task force committees to confronted it and to suggest measures and methods to reduce it practically. Examples of such efforts are: [1]; [2]; [3]; [4]; [5];; and [6]. Those works have led to the formation of a framework for NRW estimation under different water utilities operating systems and for various networks characteristics. Along the same purpose IWA and others developed internet sites to disseminate information on the progress and to train on the field at the same time.

In the Arab region and under the Arab League umbrella, Arab Countries Water Utilities Association (ACWUA) held several conferences in the subject. Several case studies and success stories from several countries, including Middle East and North Africa, were presented and discussed thoroughly. The latest conference, which held in Rabat/Morocco in 2010, the participants stressed on the need for accurate metering, making public awareness campaigns and establishing public-private partnership for NRW control [7]; while its latest workshop, which held in Amman in 2018 stressed on the formulation of a strategy and road map [8].

Since 2000 Jordan conducted several pilot studies to unveil the causes of NRW and to make recommendations to water utilities management on how to reduce it. The Japan International Cooperation Agency (JICA) conducted several pilot projects in two notable times: 2005-2008 and 2009-2011 along the same lines [9]. The initial works were in the form of field surveys to replace deteriorated pipes, customer faulty meters and to upgrade and expand the subscribers' databases and billing systems to include more customers and consequently increase revenues.

Since 2009 the Ministry of Water and Irrigation/Water Authority of Jordan [10] have embraced new policies and plans to reduce NRW. It adopted several plans to replace aged and frequently burst pipes, deteriorated service connections and faulty meters. Later, it realized the need to change water management strategy and policy to confront NRW practically by establishing private companies working on commercial basis. The new policy urged water companies to conduct pipe and service connections surveys regularly, establish 'District Metered Areas (DMAs)' based on pressure and elevation difference, issuing licensing systems for appropriate service connection installation, and install systems like Supervisory Control and Data Acquisition (SCADA) which controls pressure and flow in the DMAs within conceivable limits.

The United States Agency for International Development [11] joint MWI/WAJ in implementing the new policies by funding several NRW projects, focused on identifying the root causes of NRW, strengthening water utility assets on the ground and upgrading the institutional capacity.

Later the need for public participation was realized, because in all pilot projects the illegal consumption constitutes good proportion of the NRW. To confront it they pledged for strong institutional resolve and proposed costumers' participation is key to resolve it. Some studies proposed solutions based on financial incentives to encourage customers in low income areas abandon illegal uses or utility tapping. For example, [12] 
proposed financial incentives to force customers abide by rule of law in Zarqa City, which is the poorest and second largest city in Jordan. According to them this solution is better than other policies like the existing 'no pay policy'.

Despite all efforts spent so far to reduce NRW, the latest publication by MWI/WAJ [13] showed that more than $50 \%$ of the networks water is lost to NRW. This work will shed light on Jordan efforts to confront the NRW high value in Jordan; to recapitulate on the lessons learned up to date from those efforts and to propose a strategy and work plan applicable a Jordan situation and countries sharing the same situation like Jordan.

\section{JORDAN NRW REDUCTION EFFORTS}

JICA [9] in 2005-2008 and 2009-2011 conducted several projects in ten Jordanian governorates seeking effective methods to reduce NRW. The projects were basically leakage surveys, which identified leaking pipes and house connections, repaired the leaks and replaced the customers' faulty meters. The surveys were repeated several times and NRW was reassessed each time by two methods: flow balance calculations and minimum night flow. The recommendations of the first period projects were: (a) make frequent public awareness campaigns to convince customers abandoning the illegal connection practices, (b) convene NRW capacity building programs to train workers in the field on the best NRW control measures, and (c) use GIS in water networks layout and in developing subscribers' database and billing systems. The second period projects covered six pilot areas in whole Jordan and was based on achieving pre-set targets, for example reducing NRW by half. These projects achieved those targets after implementing several countermeasures.

In 2004 the MWI/WAJ commissioned private companies to manage water distribution in Amman and handle NRW on a commercial basis. To this purpose those companies conducted the followings: (1) performed water network inventories in small sized areas for service connections, customer meters, and other network components; (2) established number of DMAs to control pressure in the water network within the allowable limits; and (3) perform pipe network surveys and audits on a regular basis using IWA standard methodology [2]. The private companies were first tested NRW control in Madaba between 2005 to 2011, a small city south of Amman [14]. It is relatively small (19500 customers), $94 \%$ of them are households. The city has long history of weak billing and collection system errors, illegal tapping to water utilities; and old network, service connections and customer meters. After the implementation, the revenues and water volume savings rose by $160 \%$ and
$159,000 \mathrm{~m}^{3}$, respectively from 2005 baseline values. On financial basis the benefits surpassed the incurred costs of NRW control measures. The success in Madaba led to further applications in Balqa and Karak Governorates in years 2011 and 2012. Likewise, the revenues surpassed the incurred costs by relatively $40 \%$.

Because pressure in mountainous areas is one main factor to aggravate NRW, several pilot projects used pressure reduction to control NRW. Two pilot projects, one in Fuheis/Balqa Governorate and another one in Sanfahah and Arwayyemm /Tafieleh Governorate were conducted [14]. In Fuheis a $57 \mathrm{~m}$ pressure reduction reduced NRW by $18 \%-36 \%$ range; while in Sanfahah and Arwayyemm a $44 \mathrm{~m}$ pressure reduction reduced NRW by $40 \%-15 \%$. Meanwhile, those reductions in pressure resulted in significant reduction of burst complaints.

As mentioned by [15] Dorsch Gruppe, Engicon and sebaKMT conducted a project to reduce real losses in Ain Al Basha in the period between January 2007 to December 2008. The town, which located few kilometers north of Amman, has 4098 customers, rough mountainous terrain and water network with record real losses. The implementation was made in two phases, Phase 1 was data collection and SCADA system installation, by which pressure and flow at any point in the network can be controlled remotely. Phase 2 was an extensive on-job training to control high pressure in the water network by using pressure reducing valves (PRVs). The project succeeded in reducing NRW from $47 \%$ to $30 \%$.

MWI/WAJ in 2009/2010 commissioned El Concorde Construction of Jordan [16] to incorporate modern technologies in the Amman water network for the purpose of reducing NRW. Three old districts were selected for piloting: Al Nuzha, Upper Hashmi, and Lower Hashmi. The work unexpectedly was a nightmare to the two companies, they spent the first months after start-up in June 2008 trying to isolate the three districts network from large one with little success. After several trials they discovered some feeders were undocumented in the drawings in their hands, and they had to find them by trial and error. Meanwhile and part of their assignment too, they discovered that the existing billing and collection system ' $\mathrm{X} 7$ ' has serious pitfalls, it has customers names appear in the wrong areas (Table 1). Not to mention, as shown in Table 2, that a good percentage of customer meters read zero flow (for example, 29\% in Al Nuzha), which means meter by-passed was practiced there. Their work showed also that a good percentage of house connections were leaking or faulty 'unable to read', Table 2. The work lasted one full year and failed to install the intended technologies and could not calculate NRW various components.

Table 1: Pitfalls of the billing system

\begin{tabular}{|c|c|c|c|}
\hline & Al Nuzha (23B) & Upper Hashmi (29B) & Lower Hashmi (30A) \\
\hline Number of customers & $4,993(100 \%)$ & $3,837(100 \%)$ & $2,524(100 \%)$ \\
\hline Customers names appeared in the correct district & $2556(51 \%)$ & $2327(61 \%)$ & $1344(53 \%)$ \\
\hline Customers names appeared in the incorrect district & $1985(40 \%)$ & $740(19 \%)$ & $410(16 \%)$ \\
\hline
\end{tabular}


International Journal of Engineering Research and Technology. ISSN 0974-3154, Volume 13, Number 8 (2020), pp. 1968-1973

(C) International Research Publication House. https://dx.doi.org/10.37624/IJERT/13.8.2020.1968-1973

Table 2: NRW suspected causes

\begin{tabular}{|l|c|c|c|}
\hline & Al Nuzha (23B) & Upper Hashmi (29B) & Lower Hashmi (30A) \\
\hline Rolled meters & 1794 & 2002 & 1123 \\
\hline Number of house connection leaks & $50(7 \%)$ & $6(0.7 \%)$ & $28(4 \%)$ \\
\hline Meters unable to read & $120(7 \%)$ & $44(2 \%)$ & $34(3 \% 0$ \\
\hline Zero-meter reading & $519(29 \%)$ & $?$ & $?$ \\
\hline
\end{tabular}

USAID [17] recently funded a project (MESC) aiming at reducing NRW in Amman, Zarqa, Madaba, and Aqaba. Implementation was planned in two phases: Phase I (20152019) aimed at district isolating, restructuring and rehabilitating networks, detecting and repairing leak, replacing meters, and controlling pressure via advanced technologies. Phase II (2019-2023) builds on works in Phase I, incorporate SCADA systems and develop NRW reduction master plan.

Examples of projects implemented in Phase I were: Aqaba in 2017/2018, Marj Al Hammam, Marka, Abu Alanda and Tariq in 2016. In Aqaba the old district' bulk meters were found underestimating the flow by $25 \%$ and unable to measure flows below 15 1/hour. They were replaced, as a trial, in two districts by smart meters, the results showed a reduction of NRW from $56 \%$ to $22 \%$. It was then recommended to replace old the districts meters with smart ones and incorporate SCADA system in the network to keep flow and pressure under control. In other areas, it was found that NRW can be reduced from $45 \%$ to less than $25 \%$ by only adjusting districts' boundaries and replacing main feeders. Further reductions could be attained by implementing leak detection and repair measures.

In Phase II the NRW reduction master plan is under development. It will be developed on the IWA experience and diagnostic tools, the Arab League "ACWUA Impact Lifecycle" (Assess, Prevent, Monitor, Inspect, Treat, and Classify) (ACWUA, 2018), two experts experience in the area (one regional and another international) and Jordan current management team. The plan starts by collecting data on the ground, assess and filling gaps, build a vision on those results, categorize the water utilities according to the difficulties they will pose on the implementation, devise a strategy and action plan which prioritizes actions on costs. The work is very ambitious, it requires building extensive capacities and allocating intensive resources for implementation, which scrutinizes its viability and compromise it sustainability once the project concluded.

\section{BETTER STRATEGY AND ACTION PLAN}

One should develop a strategy for Jordan based on lessons learnt from pilot projects in the last 20 years. The strategy must be simple, practical and reflects situations on the ground, because the main three companies (Miyahuna, Yarmouk and Aqaba) managing water distribution in Jordan have very limited human and financial resources, which are in principle depended on governmental and foreign aids. In literature [1] provided good guidelines for developing a strategy for NRW reduction in the developing countries in the form of answers to four basic questions: How much water is being lost? Where is being lost from? How to improve performance? How to maintain the strategy? Along those lines Table 3 was prepared from pilot projects and other studies conducted in Jordan. For Question 1 the answer is: $45 \%$ to $55 \%$ is the NRW, which was calculated by applying IWA Standard Method, it is a rough number given the isolation problem and lack of meters, repair and replace policies, etc. In Question 2 the answer gave most important reasons: small pipes and house connections leaks, illegal uses and meters inaccuracies. The answer to Question 3 most of the reasons why NRW is still high in Jordan. The strategy and its approach of implementation is the answer to Question 4. First the objectives were highlighted and then the approach is presented, which based on prioritizing districts and actions before moving to next prioritized areas. In this manner the resource use efficiency is maximized, and sustainability secured by actions fitted to finance. Later, if resources and skills become available the implementation can be extended to include many areas. Though the plan is restricted for implementation to some areas, it does not mean the reconstruction, rehabilitation, and other plans in other areas should stop, instead the NRW reduction works continue in those area, but at the level of prioritized one.

Table 3: Building NRW reduction strategy and workplan for Jordan

\begin{tabular}{|c|c|c|}
\hline Question & Task & Answer \\
\hline $\begin{array}{l}\text { 1. HOW MUCH WATER IS } \\
\text { BEING LOST? } \\
\text { - Measure components }\end{array}$ & $\begin{array}{l}\text { WATER BALANCE } \\
\text { 1. Improved } \\
\text { estimation/measurement } \\
\text { techniques } \\
\text { 2. Meter calibration policy } \\
\text { 3. Meter checks } \\
\text { 4. Identify improvements to } \\
\text { recording procedures }\end{array}$ & $\begin{array}{l}\text { 1. By mass balance method: (Delivered minus } \\
\text { Consumed/Delivered) the pilot projects } \\
\text { original NRW percentage is between } 45 \% \text { - } \\
55 \% \text {. } \\
\text { 2. No meter calibration policy is in place } \\
\text { 3. Meters repaired/replaced upon meters' readers } \\
\text { reporting } \\
\text { 4. From records, no documentation on leaks } \\
\text { locations and characteristics }\end{array}$ \\
\hline
\end{tabular}




\begin{tabular}{|c|c|c|}
\hline Question & Task & Answer \\
\hline $\begin{array}{l}\text { 2. WHERE IS IT BEING LOST } \\
\text { FROM? } \\
\text { - Quantify leakage } \\
\text { - Quantify apparent losses }\end{array}$ & $\begin{array}{l}\text { NETWORK AUDIT } \\
\text { 1. Leakage studies (reservoirs, } \\
\text { transmission, mains, distribution } \\
\text { network) } \\
\text { 2. Operational/customer } \\
\text { investigations }\end{array}$ & $\begin{array}{l}\text { 1. Pilot projects: Small diameter Polyethylene } \\
\text { (PE) pipes and house connections are dominant } \\
\text { leakers. } \\
\text { 2. Pilot projects: Illegal uses and customer meter } \\
\text { inaccuracies are partially resolved }\end{array}$ \\
\hline $\begin{array}{l}\text { 3. WHY IS IT BEING LOST? } \\
\text { - Conduct network and } \\
\text { operational audit }\end{array}$ & $\begin{array}{l}\text { REVIEW OF NETWORK } \\
\text { OPERATING PRACTICES } \\
\text { 1. Investigate: historical reasons } \\
\text { - poor practices } \\
\text { - quality management procedures } \\
\text { - poor materials/infrastructure } \\
\text { - local/political influences } \\
\text { - cultural/social/financial factors }\end{array}$ & $\begin{array}{l}\text { 1. Intermittent Water Supply (IWS). In such } \\
\text { supply type the NRW is affected by area } \\
\text { characteristics, pressure, and supply startup and } \\
\text { duration. Also, it disturbs continuous } \\
\text { monitoring and destroy asset fast. } \\
\text { 2. Amman water network is still containing old } \\
\text { segments, though about } 65 \% \text { have been } \\
\text { upgraded or replaced since } 2000 \text {. } \\
\text { 3. Large part of Amman network is unsegmented } \\
\text { into DMAs. } \\
\text { 4. The network is intermingled and contain } \\
\text { undocumented area feeders } \\
\text { 5. Small PE pipes and service connections break } \\
\text { regularly by high pressure and repairing is } \\
\text { below standards. } \\
\text { 6. Little use of smart technologies } \\
\text { 7. Lack of continuous monitoring systems for } \\
\text { flow \& pressure measurements } \\
\text { 8. Illegal tapping in low income areas (situation } \\
\text { though has improved) } \\
\text { 9. NRW staff is small in numbers and expertise is } \\
\text { limited. } \\
\text { 10. In complete records of the customers and their } \\
\text { exact locations. } \\
\text { 11. Records of leaks characteristics and locations } \\
\text { are not done properly } \\
\text { 12. Costs surpassed revenues (compensated by } \\
\text { government and outsiders' aids) } \\
\text { 13. Complete lack of inspection campaigns } \\
\text { 14. The billing systems X7 is still short }\end{array}$ \\
\hline $\begin{array}{l}\text { 4. HOW TO IMPROVE } \\
\text { PERFORMANCE? } \\
\text { - Design a strategy and action } \\
\text { plans }\end{array}$ & $\begin{array}{l}\text { UPGRADING AND STRATEGY } \\
\text { DEVELOPMENT } \\
\text { 1. Update records systems } \\
\text { 2. Introduce zoning } \\
\text { 3. Introduce leakage monitoring } \\
\text { 4. Address causes of apparent } \\
\text { losses } \\
\text { 5. Initiate leak detection/repair } \\
\text { policy } \\
\text { 6. Design short/medium/long term } \\
\text { action plans }\end{array}$ & $\begin{array}{l}\text { The NRW Strategy and Workplan } \\
\text { The strategy must be easily implemented, resource } \\
\text { efficient and realized learnt lessons from pilot } \\
\text { projects and works conducted so far in Jordan. } \\
\text { Its approach is to prioritize areas to where it is } \\
\text { applied. It is basic steps: isolate, divide into } \\
\text { DMAs, assess, treat and iterate till targets are met. } \\
\text { Sustain targets by monitoring and inspection. } \\
\text { Make plans and learn and adjust during } \\
\text { application. } \\
\text { Its objectives are: } \\
\text { 1. Build on previous networks isolation, } \\
\text { restructuring and rehabilitation works. } \\
\text { 2. Optimize resources because costs will not be } \\
\text { recovered fully. Companies are restrained by } \\
\text { government-based tariffs and subsidies. } \\
\text { 3. NRW reduction is target oriented and its } \\
\text { sustainability should be given special } \\
\text { attention. } \\
\text { 4. Public participates in its implementation. }\end{array}$ \\
\hline
\end{tabular}




\begin{tabular}{|c|c|c|}
\hline Question & Task & Answer \\
\hline & & $\begin{array}{l}\text { The Workplan } \\
\text { The workplan ankle heels are prioritization of } \\
\text { districts on which NRW must be practiced. From } \\
\text { pilot projects outcomes and other works so far, the } \\
\text { following workplan can be suggested: } \\
\text { 1. Classify service area into priority areas, based } \\
\text { on customers consumption, loss frequency and } \\
\text { type and implementation constraints } \\
\text { (technical, financial, etc.), for example, } \\
\text { Priority Area } 1,2 \text {, 3, etc. } \\
\text { 2. In Priority Area 1, do the following in a } \\
\text { repetitive manner: (a) isolate the area from } \\
\text { parent network, (b) form DMAs within it } \\
\text { based on pressure and boundary lines } \\
\text { adjustment, (c) assess loss by IWA Standard } \\
\text { method and (d) treat the loss causes according } \\
\text { to reduction efficiency. Repeat actions c and d } \\
\text { until the pre-set water balance targets are met. } \\
\text { 3. Sustain the pre-set targets reached in Priority } \\
\text { Area } 1 \text { by installing a monitoring system and } \\
\text { by doing inspection. } \\
\text { 4. Move to Priority Area } 2 \text { and repeat Steps } 2 \\
\text { and } 3 \text {. } \\
\text { 5. Repeat Step } 4 \text { to Priority Area } 3,4 \text { and so on. } \\
\text { 6. Stop per resources sufficiency. } \\
\text { During the workplan implementation, develop } \\
\text { plans for meters and pipe replacement and } \\
\text { repairing, records and billing systems upgrading, } \\
\text { and customers' incentive. Simultaneously, try to } \\
\text { modify methods, procedures, indicators, etc. } \\
\text { according to learning lessons }\end{array}$ \\
\hline $\begin{array}{l}\text { 5. HOW TO MAINTAIN THE } \\
\text { STRATEGY? }\end{array}$ & $\begin{array}{l}\text { POLICY CHANGE, TRAINING } \\
\text { AND O\&M } \\
\text { Training: improve awareness } \\
\text { increase motivation } \\
\text { transfer skills } \\
\text { introduce best practice/technology } \\
\text { O\&M: Community involvement } \\
\text { Water conservation and demand } \\
\text { management programs } \\
\text { Action plan recommendations O\&M } \\
\text { procedures }\end{array}$ & $\begin{array}{l}\text { 1. Because NRW works in Jordan are driven by } \\
\text { governmental and foreign aids, it is imperative } \\
\text { to illustrate good performance by indicators } \\
\text { and transparent process. } \\
\text { 2. Build a partnership with organizations like } \\
\text { ACWUA and scientific institutions for help in } \\
\text { capacity building and technology transfer. } \\
\text { 3. Develop performance-based incentives to the } \\
\text { workers on NRW reduction activities, } \\
\text { including operation and maintenance. } \\
\text { 4. Establish a good working team on NRW in any } \\
\text { company and give it some authority on the } \\
\text { company units. } \\
\text { 5. Develop in-house manuals and a practice } \\
\text { doctrine for those working on NRW. }\end{array}$ \\
\hline
\end{tabular}

\section{DISCUSSION AND CONCLUSIONS}

Jordan conducted since 2000 several NRW pilot projects to unveil causes, quantify and resolve them. The projects showed that the loss is caused mainly by leaked service connections, meters inaccuracy (customers' meters, in particular), high pressure, illegal tapping to water utilities and supply intermittency. Though of the efforts exerted since then, NRW is still high at $50 \%$, and the reasons may be:

1. The water networks are still intermingled, not isolated fully, and some contain undocumented feeders on papers.

2. The customers' billing systems are inaccurate.

3. No meters' replacement plan or policy is in place and meters may underestimate or overestimate consumption 
International Journal of Engineering Research and Technology. ISSN 0974-3154, Volume 13, Number 8 (2020), pp. 1968-1973

(C) International Research Publication House. https://dx.doi.org/10.37624/IJERT/13.8.2020.1968-1973

due to meter sensitivity and reading accuracy.

4. Illegal tapping to the water network still exists, especially in low income areas. It requires practical solutions based on incentives or other means.

5. The supply intermittency is blamed for high NRW, because it deteriorates water assets quickly. Nevertheless, its estimation is affected the pressure value and number of served customers.

Based on the above, it can be concluded that:

1. NRW in Jordan is still be difficult to estimate due to the previous challenges.

2. The billing systems must be re-checked and re-verified regularly to include more customers and increase revenues.

3. A new policy should be adopted for illegal uses in low income areas, it may be based on customers' incentives.

4. Public-private partnership must be nourished and expanded to other places in Jordan to efficient use the water resource and to reduce the incurred costs.

5. SCADA or other data monitoring systems must be installed in mountainous areas to control pressure and preserve assets from deteriorating.

Based on the above a new strategy drawn from [1] was proposed. It is considered appropriate for Jordan because it builds on the real situation learnt from pilot projects and other works in Jordan.

\section{REFERENCES}

[1] M Farley, and R. Liemberger, Developing a non-revenue water reduction strategy: planning and implementing the strategy, Water Science and Technology: Water Supply, 2005, 5. 10.2166/ws.2005.0006.

[2] A Lambert, and W. Hirner, Losses from water supply systems: standard terminology and recommended performance measures, in The Blue Pages. International Water Association, (London, UK, 2000).

[3] R McKenzie, and A. Lambert, Economic model for leakage management for water suppliers in South Africa, Water Research Commission, 2002. [Online].

www.wrc.org.za/other\%20documents/software/econolea $\mathrm{k} / \mathrm{tt} \% 20169-02 . p d f$

[4] J Thorton, Managing leakage by managing pressure-a practical approach, Water 21, Article No. 33-IWA Water Loss Task Force, 2003. [Online]

http://aquageo.es/wp-

content/uploads/2012/10/managing-leakage-by-

managing-pressure.pdf

[5] P Fanner, Assessing real losses, including component analysis and economic considerations: a practical approach, Water21 Article, No 6, IWA Publishing, London 2004.

[6] A Lambert, and R. Taylor, Water loss guidelines, (Water New Zealand - The New Zealand Water \& Wastes
Association, Wellington, New Zealand, 2010). [Online] www.waternz.org.nz/Folder?Action=View\%20File\&Fol der_id=101\&File=100503_waterloss_guidelines.pdf

[7] Arab Countries Water Utilities Association (ACWUA), Non-revenue water management: solutions for drinking water loss reduction Arab countries, (3rd ACWUA Best Practice Conference, Rabat, Morocco, 20-21 January 2010). [Online]

https://acwua.org/event/third-acwua-best-practiceconference-non-revenue-water-in-the-arab-regionsolutions-for-drinking-water-loss-reduction/

[8] Arab Countries Water Utilities Association (ACWUA), Non-revenue water (NRW) reduction master planknowledge sharing workshop, Amman, Jordan, 2018.

https://acwua.org/acwua-news/non-revenue-water-nrwreduction-master-plan-knowledge-sharing-workshop/

[9] JICA's Cooperation for water sector in Jordan, capacity development project for non-revenue water reduction in Jordan-Phase 1 (2005 - 2008), Phase 2 (2009-2011), Amman, Jordan, 2011. [Online]

https://www.jica.go.jp/jordan/english/activities/pdf/activ ity_01.pdf

[10] Ministry of Water and Irrigation (MWI), Water for life: Jordan's water strategy 2008-2022', Amman, Jordan, 2009.

[11] D Humpal, H. El-Naser, K. Irani, J. Sitton, K. Renshaw, and B. Gleitsmann, A review of water policies in Jordan and recommendations for strategic priorities 2012. [Online].

[12] T AL-Washali, S. Sharma, M. Kennedy, Methods of assessment of water losses in water supply systems: a review, Water Resources Management, 30, pp. 498550012016, 2016.

[13] Ministry of Water and Irrigation /Water Authority of Jordan, Water sector: facts and figures, Amman, Jordan, pp. 14. 2015. [Online]

[14] Mustafa Nasereddin, in Documentation of best practices in non-revenue water in selected Mediterranean countries - Algeria, Israel, Jordan \& Morocco', Sustainable Water Integrated Management (SWIM) - Support Mechanism, EU Project, 2013.[Online]

http://www.swim-sm.eu/

[15] cats.carpha.org,

Technical_manual_en_guidelines_case_studies, 2014 [Online]

http://cats.carpha.org/Portals/1/images/2014/08/Technic al_Manual_EN_Guidelines_Case_Studies.pdf

[16] El Concorde Construction, Amman non-revenue water reduction', Final Report, 2010. (Unpublished report)

[17] USAID, Non-revenue water in Jordan (MESC project, 2015) [Online]

https://jordankmportal.com/organizations/mesc-nonrevenue-water 